\title{
LARUTAN DAUN SALAM (Syzygium polyanthum) SEBAGAI PENGAWET ALAMI PADA IKAN SELAR KUNING (Selaroides leptolepis)
}

\author{
Rahim Husain*1, Fitriyanti Musa² \\ ${ }^{1}$ Dosen Teknologi Hasil Perikanan, FPIK, Universitas Negeri Gorontalo, \\ 2Mahasiswa Teknologi Hasil Perikanan, FPIK, Universitas Negeri Gorontalo \\ Jl.Jenderal Sudirman No.06, Kota Gorontalo 96128, Gorontalo, Indonesia \\ *Korespondensi: imrahim76@yahoo.co.id \\ (Diterima 03-08-2020; Direvisi 10-12-2020; Dipublikasi 28-01-2021)
}

\begin{abstract}
Abstrak
Penelitian ini bertujuan untuk mengetahui pengaruh lama penyimpanan terhadap mutu ikan selar kuning (Selaroides leptolepis) segar yang direndam menggunakan larutan daun salam (Syzygium polyanthum). Perlakuan pada penelitian ini yaitu penggunaan larutan daun salam $9 \%$ dengan lama penyimpanan 0 jam, 6 jam, 12 jam, 18 jam, 24 jam dan 30 jam. Parameter yang diuji yaitu TPC dan pH. Analisis data yang digunakan pada uji Kimia dan mikrobiologi menggunakan RAL (anova). Hasil yang berpengaruh nyata dilanjutkan dengan uji Duncan. Berdasarkan hasil penelitian menunjukkan bahwa penggunaan larutan daun salam 9\% mampu mempertahankan mutu ikan selar kuning (Selaroides leptolepis)segar selama penyimpanan 12 jam dengan memiliki nilai pH 6,08 dan secara mikrobiologi diperoleh nilai ALT yaitu 5,49 CFU/g, hal ini memenuhi SNI 2729.2013 tentang ikan segar.
\end{abstract}

Kata Kunci : Larutan Daun Salam: Selaroides leptolepis; TPC; pH

\section{Salam Leaves Solution (Syzygium polyanthum) As Natural Preservative for Yellow Cellar Fish (Selaroides leptolepis)}

\begin{abstract}
This study aimed to determine the effect of storage time on the quality fresh of yellowfish (Selaroides leptolepis) soaked using Salam leaf solution (Syzygium polyanthum). The treatment in this study was the use of $9 \%$ Salam leaf solution with a storage time of 0 hours, 6 hours, 12 hours, 18 hours, 24 hours and 30 hours. The parameters tested were TPC and pH. Analysis of the data used in chemical and microbiological tests using CRD (Anova). Results that had a significant effect were followed by Duncan's test. Based on the results of the study showed that the use of Salam leaf solution $9 \%$ was able to maintain the quality of fresh selaryellow of fish (Selaroides leptolepis) during 12 hours storage with a $\mathrm{pH}$ value of 6.08 and microbiologically obtained ALT values of $5.49 \mathrm{CFU} / \mathrm{g}$, this siutable SNI 2729.2013 concerning fresh fish.
\end{abstract}

Keywords: Selaroides leptolepis; Salam Leaf Solution; TPC; pH

http://ejurnal.ung.ac.id/index.php/ffpj/issue/arch 


\section{PENDAHULUAN}

Provinsi Gorontalo merupakan daerah yang potensial dibidang perikanan. Salah satu potensi perikanan tangkap di perairan Gorontalo yang memiliki nilai ekononmis yaitu ikan selar kuning (Selaroides leptolepis). Potensi ikan selar kuning pada tahun 2017 mencapai 874,375 ton (DKP, 2017). Ikan selar kuning (Selaroides leptolepis)merupakan salah satu komiditi pangan laut yang mudah mengalami kemunduran mutu. Hal ini disebabkan oleh kandungan protein yang tinggi yaitu sekitar 19, 98\%, kadar air $79,48 \%$, kadar lemak 2,12\% kadar abu 0,93\% dan kondisi lingkungan yang sangat sesuai untuk pertumbuhan mikroba pembusuk (Nurnadia et al., 2011).

Kondisi lingkungan tersebut yaitu suhu, pH, oksigen, waktu simpan dan kondisi kebersihan sarana prasarana. Oleh karena itu, dibutuhkan proses pengawetan yang bertujuan menghambat atau mencegah terjadinya kerusakan, mempertahankan mutu, menghindari terjadinya keracunan, danmempermudah penanganan dan penyimpanan. Untuk menghindari pengawetan menggunakan bahan kimia yang berdampak buruk bagi kesehatan, dibutuhkan pengawet yang bersumber dari bahan alami (Mawaddah, 2008). Salah satu usaha untuk mempertahankan kesegaran ikan yaitu dengan menambahkan zat aditif yang aman untuk dikonsumsi serta alami, mengingat dewasa ini banyak sekali penjual ikan yang menggunakan zat aditif yang berbahaya seperti formalin untuk menjaga kesegaran ikan yang tidak dianjurkan sebab dapat mengganggu kesehatan (Sahputra, 2015). Zat aditif yang aman untuk dikonsumsi dan alami yang dapat dijadikan pengawet agar ikan tetap segar yaitu dengan menggunakan tanaman rempah.Salah satu tanaman rempah yang dapat dimanfaatkan sebagai pengawet alami yaitu tanaman salam (S. polyanthum).

Tanaman salam(S. polyanthum) merupakan tanaman berkayu yang biasanya dimanfaatkan daunnya. Daun salam memiliki kandungan kimia seperti minyak atsiri $(0,05 \%)$ yang mengandung sitral, eugenol, tannin dan flavonoid, sehingga dapat digunakan sebagai pengawet alami (Sudirman, 2014). Komponen-komponen ini yang mampu menghambat bakteri patogen. Beberapa hasil penelitian mengenai bahan pengawet alami daun salam dan ikan selar yang telah dilakukan: ikan bandeng direndam daun salam 7\% kombinasi garam 8\% dapat memperpanjang daya awet ikan dengan jumlah bakteri 5,2 $\times 10^{5}$ CPU/g (Sahputra, 2015); pelumuran bubuk cengkeh pada ikan selar dapat mempertahan mutu organoleptik selama 12 jam (Yusuf et al., 2019). Susilowati dan Harningsih (2017), menyatakan bahwa perendaman ikan layur dalam ektrak daun salam dalam dengan variasi konsentrasi yaitu 0\%,3\%,5\%,7\% dan 9\% selama 15 menit dapat menghambat pertumbuhan bakteri. Akan tetapi,perendaman ikan layur pada konsentrasi $7 \%$ lebih banyak disukai panelis dari segi tekstur, aroma dan rasa. Hal inilah yang mendasari penulis 
melakukan penelitian tentang penggunaan daun salam sebagai bahan pengawet untuk mempertahankan mutu organoleptik dan kimia pada ikan selar kuning segar. Pengawetan bertujuan untuk mengetahui efek peran daun salam yang ditambahkan air sebagai pengawet tunggal pada ikan segar.

\section{METODE PENELITIAN}

\section{Waktu dan Tempat Penelitian}

Pelaksanaan penelitian ini dilaksanakan pada bulan Agustus - September. Pengujian organoleptik bertempat di laboratorium Jurusan Teknologi Hasil Perikanan Fakultas Perikanan dan IImu Kelautan Universitas Negeri Gorontalo. Pengujian kimia dan mikrobiologi dilakukan di Balai Pembinaan dan Pengujian Hasil Perikanan (BPPMHP) Provinsi Gorontalo.

\section{Alat dan Bahan}

Alat yang digunakan pada penelitian antara lain coolbox sebagai wadah penyimpanan, $\mathrm{pH}$ meter, mesin penggiling atau blender, timbangan digital, pisau, talenan, magnetic stirrer, hot plate, autoclave, cawan, incubator, oven, mikropipet, label, loyang, tabung erlenmeyer, gelas beker, tabung reaksi, waterbath, alumenium foil, laminary air flow, Tisu.

Bahan baku ikan selar kuning yang dijadikan sampel pada penelitian ini berasal dari TPI Kota Gorontalo dan Daun Salam yang diperoleh dari Pasar Sentral Kota Gorontalo. Bahan yang digunakan untuk analisis Total Plate Count (TPC) yaitu Media NA (Natrium Agar), Media PCA (Plate Count Agar), aquades, Butterfield Phosphate (BFP) dan analisi pH yaitu Larutan Buffer Solution pH 7,0,pH 4,0, Aquades, $\mathrm{NaOH}$.

\section{Prosedur Penelitian}

Penelitian ini dilakukan dua tahap yakni tahap penelitian pendahuluan dan tahap penelitian utama. Penelitian pendahuluan bertujuan untuk melihat titik perubahan yang terjadi selama penyimpanan dan dikontrol setiap 1 jam tujuannya untuk menentukkan range waktu yang akan digunakan pada penelitian utama Serta untuk menentukan kosentrasi terbaik larutan daun salam.

Penelitian utama bertujuan untuk mengetahui pengaruh lama penyimpanan terhadap mutu ikan selar kuning segar yang direndam menggunakan larutan daun salam. Berdasarkan hasil penelitian pendahuluan maka konsentrasi larutan daun salam yang digunakan yaitu 9\% dengan berat ikan $\pm 110 \mathrm{~g} / \mathrm{ekor}$. Pengujian dilakukan pada ikan selar yang direndam dengan daun salam selama penyimpanan yaitu pengujian Mikrobiologi (TPC) dan kimia (pH). 


\section{HASIL DAN PEMBAHASAN}

\section{Nilai Total Plate Count (TPC) Ikan Selar Kuning}

Data hasil analisis pengaruh lama penyimpanan terhadap nilai TPC ikan selar kuning dapat dilihat pada Gambar 1. Data hasil penelitian nilai TPC ikan selar kuning berada pada interval 3,60 CFU/g -6,62 $\mathrm{CFU} / \mathrm{g}$. Nilai terendah terdapat pada perlakuan lama penyimpanan 30 jam dan nilai tertinggi terdapat pada perlakuan 0 jam (kontrol). Berdasarkan hasil uji Anova dan uji Duncan menunjukkan bahwa lama penyimpanan 0 jam (kontrol) berbeda nyata dengan semua perlakuan. Tetapi perlakuan 24 jam dan 30 jam tidak berbeda nyata.

Menurut BSN (2013) jumlah bakteri ALT pada ikan segar adalah 5x105koloni/g (dikonversi dalam bentuk nilai logaritma menjadi 5,699 CFU/g). Berdasarkan batasan tersebut, hasil perlakuan lama penyimpanan konsentrasi daun salam 9\% dapat mempertahankan mutu mikrobiologis ikan hingga 12 jam dibanding dengan perlakuan 18 jam, 24 jam dan 30 jam. Nihali et al., (2020), menyatakan bahwa perlakuan 21 jam pertumbuhan bakteri semakin banyak atau tidak dihambat oleh senyawa aktif sehingga masih memungkinkan untuk mengalami kemunduran mutu mikrobiologis yang lebih cepat

Berdasarkan hasil tersebut maka konsentrasi daun salam 9\% mampu menekan pertumbuhan bakteri selama penyimpanan 12 jam, karena pada lama penyimpanan tersebut jumlah TPC masih memenuhi standar berdasarkan SNI (2013). Hal ini disebabkan oleh senyawa antimikroba seperti minyak atsiri dalam ekstrak daun salam yang dapat menghambat pertumbuhan mikroba. Minyak atsiri tersebut memiliki kemampuan untuk menghambat pertumbuhan bakteri, dimana terjadi proses denaturasi protein yang menyebabkan perubahan struktur protein dan terjadi proses koagulasi.

Protein yang mengalami proses denaturasi akan kehilangan aktifitas fisiologi dan dinding sel akan meningkatkan permeabilitas sel sehingga akan terjadi kerusakan (Sumono dan Wulan, 2009). Akan tetapi seiring dengan lamanya penyimpanan menyebabkan kemunduran mutu ikan terus berlangsung, sehingga konsentrasi larutan daun salam tidak dapat lagi mempertahankan mutu kesegaran ikan dan menyebabkan mikroorganisme pembusuk terus berkembang biak. Fardiaz (1992) menyatakan bahwa mikroorganisme mempunyai berbagai enzim yang dapat memecah komponen-komponen yang mengakibatkan perubahan-perubahan dalam sifat makanan seperti rupa, rasa, bau dan tekstur. Adanya perlakuan pemberian larutan ekstrak daun mengkudu dapat menyebabkan mutu ikan kembung cukup dapat dipertahankan selama waktu yang diperlukan. Octovrisna $d k k$, (2013) menambahkan bahwa kemampuan suatu mikroorganisme sangat tergantung dari larutan konsentrasi bahan antimikroba yang digunakan,

http://ejurnal.ung.ac.id/index.php/jfpj/issue/arch 
selainitu jenis bahan antimikroba juga menentukan kemampuan menghambat pertumbuhan bakteri. Lebih lanjut jika semakin kecil dosis maka semakin sedikit jumlah zat aktif yang terkandung didalamnya sehingga semakin rendah kemampuan dalam menghambat pertumbuhan suatu bakteri.

\section{Nilai pH Ikan Selar Kuning}

Hasil penelitian lama penyimpanan ikan selar kuning yang direndam menggunakan larutan daun salam terhadap nilai pH dapat dilihat pada Gambar 2. Hasil penelitian uji pH ikan selar kuning berada pada interval $6,08-7,58$. Nilai terendah terdapat pada perlakuan lama penyimpanan 12 jam dan nilai tertinggi terdapat pada perlakuan 30 jam. Mengacu pada standar mutu ikan segar yang ditetapkan oleh BSN (27292013), bahwa pH ikan selar kuning hasil perlakuan dengan lama penyimpanan 0 jam, 6 jam, 12 jam, 18 jam, 24 jam dan 30 jam tidak disyaratkan.

Berdasarkan hasil uji Anova dan uji Duncan menunjukkan bahwa lama penyimpanan 0 jam (kontrol) tidak berbeda nyata dengan 6 jam tetapi berbeda nyata dengan semua perlakuan. Perlakuan 6 jam tidak berbeda nyata dengan 0 jam dan 12 jam tetapi berbeda nyata dengan 18 jam, 24 jam dan 30 jam. Perlakuan 18 berbeda nyata dengan semua perlakuan. Perlakuan 30 jam berbeda nyata dengan semua perlakuan kecuali dengan 24 jam.

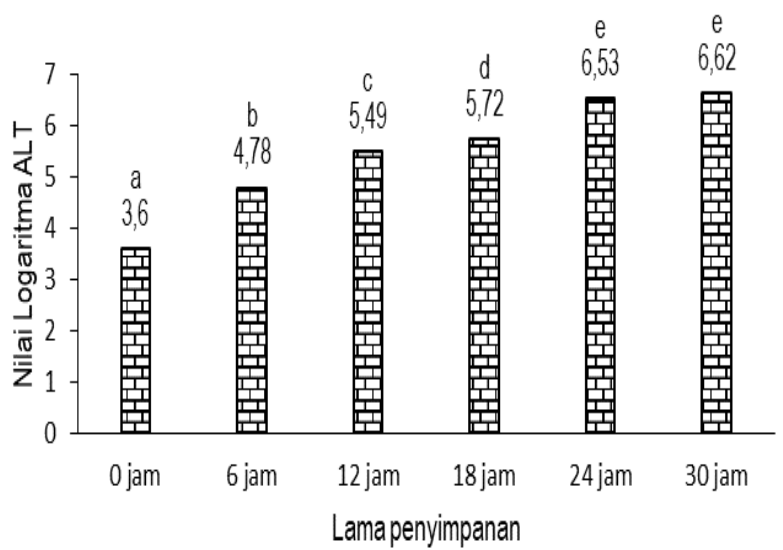

Gambar 1. Histogram hasil uji TPC

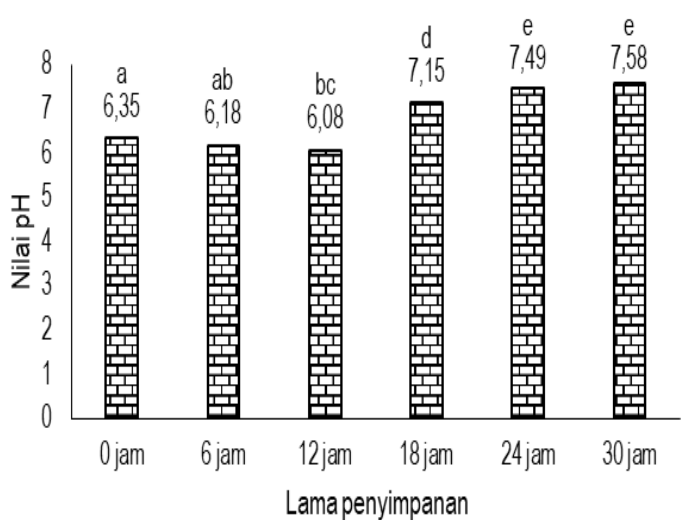

Gambar 2. Histogram hasil uji pH

Hasil penelitian menunjukkan semakin lama penyimpanan (18 jam sampai 30 jam) nilai pH ikan selar kuning semakin tinggi. Peningkatan nilai pH menunjukkan adanya aktifitas enzim proteolitik yang terdapat dalam jaringan daging ikan yang menghasilkan amonia. Sedangkan penurunan nilai pH terjadi karena adanya aktivitas mikroorganisme yang mendegradasi protein berbentuk glikogen menjadi asam laktat. Nilai 
pH mengalami kenaikan karena pembentukan ammonia akibat aktifitas enzim proteolitik (Ridwansyah, 2002). Hal ini sesuai dengan Santoso et al., (1999) bahwa penurunan pH pada peredaman disebabkan terbentuknya asam laktat hasil reaksi pemecahan glikogen oleh enzim yang terdapat dalam daging ikan. Selain itu pH ikan ikan selar kuning juga dapat dipengaruhi oleh perlakuan lama penyimpanan dengan pengguanaan larutan daun salam. Semakin lama penyimpanan, maka nilai pH pada ikan selar kuning akan semakin meningkat, hal tersebut menunjukkan bahwa aktivitas antimikroba akan semakin rendah namun kemunduran mutu akan terus berlangsung.

Menurut Nurjanah et al (2007) dalam Erlangga (2009), penguraian enzim menjadi senyawa-senyawa sederhana dimulai pada saat nilai pH aktif. Enzim tersebut mampu menguraikan protein menjadi senyawa yang lebih sederhana sehingga nilai pH kembali naik. Nilai pH daging ikan akan terus naik mendekati netral setelah fase rigor mortis berakhir. Seiring dengan bertambahnya waktu penyimpanan akan terjadi peningkatan nilai $\mathrm{pH}$ pada fase post rigor awal dan terus meningkat pada fase post rigor akhir. Nilai pH erat pula kaitanya dengan tingkat pertumbuhan bakteri, semakin rendah $\mathrm{pH}$ maka semakin rendah pula kemampuan bakteri untuk melakukan pertumbuhanya (Kasmadihardja, 2008).

Nilai $\mathrm{pH}$ merupakan salah satu indikator yang digunakan untuk menentukan tingkat kesegaran ikan. Pada proses pembusukan ikan, perubahan $\mathrm{pH}$ daging sangat besar peranannya karena berpengaruh terhadap penyerangan bakteri. pH yang baik untuk pertumbuhan bakteri yaitu berkisar antara 6-8 (Fardiaz, 1992). Yunizal dan Wibowo (1998) menambahkan ikan yang baru mati umumnya mempunyai pH netral yakni sekitar 7,0. Metusalach et al., (2012) menyatakan pH daging ikan akan mengalami penurunan hanya sampai batas tertentu yaitu sekitar pH 5,5. Hal ini terkait dengan ketersediaan cadangan glikogen dalam daging. Jika cadangan glikogen telah habis terurai maka pH daging akan berhenti mengalami penurunan. Penguraian protein dan komponen selain protein yang mengandung nitrogen selama proses kemunduran mutu akan meningkatkan $\mathrm{pH}$ daging ikan, dan semakin tinggi tingkat pembusukan maka akan semakin tinggi pula pH. Ikan busuk memiliki pH sekitar 10-11. Dilain pihak, nilai organoleptik akan terus mengalami penurunan samapai nilai terendah.

\section{KESIMPULAN}

Berdasarkan hasil penelitian mengenai penggunaan larutan daun salam dengan konsentrasi $9 \%$ terhadap mutu ikan selar kuning segar menunjukkan bahwa terdapat pengaruh yang signifikan terhadap nilai mikrobiologi (TPC), dan kimia (pH) selama penyimpanan 0 jam, 6 jam, 12 jam, 18 jam, 24 jam, dan 30 
jam. Hasil uji kimia menunjukkan bahwa ikan selar kuning segar yang direndam dengan daun salam $9 \%$

pada lama penyimpanan 12 jam memiliki pH 6,08 dan secara mutu mikrobiologi diperoleh nilai ALT yaitu 5,49 CFU/g, hal ini memenuhi SNI 2729.2013 tentang ikan segar.

\section{DAFTAR PUSTAKA}

DKP Provinsi Gorontalo. 2017. Data Hasil Tangkapan Provinsi Gorontalo. Gorontalo (ID): Dinas Kelautan dan Perikanan.

Erlangga. 2009. Kemunduran mutu fillet ikan lele dumbo (Clarias gariepinus) pada penyimpanan suhu chilling dengan perlakuan cara kematian [Skripsi]. Bogor (ID): Institut Pertanian Bogor.

Fardiaz S. 1992. Mikrobiologi Pangan. Jakarta (ID): Gramedia Pustaka Utama.

Mawaddah. 2008. Pemanfaatan bahan rempah sebagai pengawet alami untuk menghambat bakteri. [Skripsi]. Bogor (ID): Institut Pertanian Bogor.

Metusalach, Kasmiati, Fahrul, Ilham J. 2012. Analisis hubungan antara cara penangkapan dan cara penanganan dengan kualitas ikan yang dihasilkan. Laporan Hasil Penelitian LP2M. UNHAS.

Nihali MP, Sulistijowati R, Yusuf N. 2020. Pengawetan ikan tongkol (E. affinis) menggunakan sari daun jambu biji (Psidium guajava) selama penyimpanan suhu ruang. Jambura Fish Processing Journal. 2 (2): 23-31.

Nurjanah I, Setyaningsih, Sukarno, Muldani M. 2004. Kemunduran mutu ikan nila merah (Oreochromis sp.) selama penyimpanan pada suhu ruang. Jurnal Pengolahan Hasil Perikanan Indonesia. 7(1)

Sahputra WN. 2015. Daya simpan ikan bandeng yang diawetkan menggunakan pengawet alami kombinasi daun salam (Eugenia polyantha) dan garam [Skripsi]. Surakarta (ID): Universitas Muhammadiyah.

Susilowati TI, Harningsih T. 2017. Potensi ekstrak daun salam (Syzygium polyanthum) sebagai pengawet pada ikan layur (Trichiurus sp.). Jurnal KesMaDaska. 67(9): 91-95.

Yusuf F, Husain R, Naiu AS. 2019. Mutu organoleptik ikan selar (C. leptolepis) segar yang dilumuri bubuk cengkeh (S. aromaticum) selama penyimpanan. Jambura Fish Processing Journal. 1(2): 58-68. 